\title{
K ČEMU JE DOBRÁ KYSELINA FYTOVÁ?
}

\section{Souhrn}

Kyselina fytová je prrirozeně vznikající sloučenina $\mathrm{v}$ buňkách a v rostlinných vlákninách. Je známá pod jinými názvy, jako je fytát nebo inositolhexakisfosfát ( $\left.\mathrm{IP}_{6}\right)$. Zatímco je dosud známo relativně málo o její úloze v lidském těle, mnohé studie na zviŕatech ukazují, že má významné antioxidační vlastnosti, kromě dalších dosud málo prozkoumaných prospěšných účinků. Může působit preventivně proti některým typům rakoviny, jako je např́klad rakovina prsu a střev. Injekce kyseliny fytové redukovaly velikost rakovinových tumorů u myší. Kyselina fytová má rovněž prospěšné účinky v regulaci hladiny glukózy v krvi a může omezovat vznik ledvinových kamenů.

Klíčová slova: kyselina fytová - inositolhexkisfosfát - insoitolový signální systém

\section{ÚVOD}

Kyselina fytová je esterem myo-inositolu a kyseliny fosforečné (myo-inositolhexakisfosfát, $\mathrm{IP}_{6}$ ) (Raboy, 2003). Je nejrozšîrenějším inositolfosfátem na Zemi (Strunecká, 2005) a je hlavní formou zásobního fosforu v semenech rostlin: představuje 50 $85 \%$ fosforu v semenech obilovin, olejnin a luštěnin (Irvine, 2005). Na jedné straně je považována za antinutriční látku, která snižuje využití fosforu, zinku, vápníku a mědi u zvířat a lidí. Na druhé straně potlačuje tvorbu reaktivních hydroxylových radikálů katalyzovanou železem a má rovněž hypo -cholesterolemický účinek (Graf, Eaton, 1990).

\section{Kyselina fytová v lidské výživě}

Z oblasti studia výživy se nahromadily poznatky, které ukazují na význam $\mathrm{IP}_{6}$ jako fyziologicky významné složky výživy hospodářských zvírat i člověka. Tato kyselina představuje zdroj 50 $85 \%$ fosforu v semenech obilovin, olejnin a luštěnin. Soli s ionty vápníku nebo hořčíku nazývané fytiny se nacházejí ve vlákninách. Mnohé literární i internetové zdroje (např. Oatway et al., 2001) uvádějí, že suplementace potravy dostatečným množstvím $\mathrm{IP}_{6}$ má prospěšné účinky $\mathrm{v}$ prevenci rakoviny tlustého střeva a rakoviny prsu, snižuje krevní srážlivost, hladinu cholesterolu a triglyceridů (Vucenik et al., 1997; Vucenik, Shamsuddin, 2003). Uvádějí se i prospěšné účinky $\mathrm{IP}_{6}$ $\mathrm{v}$ prevenci infarktu myokardu, stimulace funkcí lymfocytů a prevence tvorby ledvinových kamenů. $\mathrm{IP}_{6}$ zasahuje i do regulace hladiny glukózy v krvi. Většina těchto tvrzení je však zatím založena na experimentech s laboratorními zviŕaty, a je proto obtížné rozhodnout, zda je kyselina fytová užitečnou, nebo naopak nebezpečnou složkou lidské výživy (Harnad, Morris, 1995).
Vysoký chelatační potenciál $\mathrm{IP}_{6}$ nabádá $\mathrm{k}$ určité opatrnosti vzhledem k možným interakcím s ionty železa, hořčíku a vápníku (Sandberg et al., 1999). Na druhé straně je tímto mechanismem $\mathrm{IP}_{6}$ účinný $\mathrm{v}$ prevenci vzniku ledvinových kamenů a inhibuje produkci iontů amonných, čímž má deodorizační účinky, snižuje zápach z úst i zápach moči. Pro své chelatační účinky je $\mathrm{IP}_{6}$ také použiván např́iklad $\mathrm{v}$ potravinářském průmyslu. Jeho pridání zkracuje potřebnou dobu fermentace a brání změnám v barvě různých potravin a vína. Vzhledem $\mathrm{k}$ vysoké schopnosti chelatace $\mathrm{s} \mathrm{Mg}^{2+}$ se patrně udržuje $\mathrm{v}$ živočišných buňkách koncentrace volného a rozpustného $\mathrm{IP}_{6}$ v rozmezí 10-60 mM (Irvine, 2005). Předpokládá se, že část $\mathrm{IP}_{6}$ je v buňkách vázána na proteiny.

\section{Kyselina fytová a CNS}

Chemická struktura $\mathrm{IP}_{6}$ (obr. 1) ukazuje, že se jedná o vysoce polární sloučeninu se šesti fosfátovými skupinami. Lze tedy předpokládat, že nemá schopnost být snadno vstřebávána, aniž by byla ve střevě defosforylována na inositol, a pronikat přes soustavy plazmatických membrán buněk střevního epitelu a kapilár do krevního oběhu a odtud do různých tkání. Grases et al., (2002) však překvapivě zjistili, že $\mathrm{IP}_{6}$ se u krys velmi rychle vstřebává $\mathrm{z}$ potravy $\mathrm{v}$ nezměněné formě. Zajímavé je zjištění, že se přednostně akumuluje v mozku. Jestliže byly krysy krmeny dietou bez $\mathrm{IP}_{6}$, jeho hladiny v plazmě byly $0.023 \pm 0.008 \mathrm{mmol} . \mathrm{L}^{-1}$, v mozku $3.35 \pm 0.57 \mathrm{mmol} \cdot \mathrm{kg}^{-1}$. Dodání IP 6 do diety výrazně zvýšilo jeho hladiny v mozku, kde byly 100 krát vyšší než v plazmě $(36.8 \pm 1.8$ vs $0.29 \pm 0.02)$. Funkce $\mathrm{IP}_{6} \mathrm{v}$ mozku, kde jsou jeho koncentrace 8,5 krát vyšší než koncentrace $\mathrm{IP}_{3}$, však zatím 
zůstává nevysvětlená. $\mathrm{V}$ buňkách hipokampu $\mathrm{IP}_{6}$ zvyšuje aktivitu L-typu $\mathrm{Ca}^{2+}$-kanálů (Yang et al., 2002), má zřejmě rovněž významnou úlohu jak při apoptóze, tak v regulaci neurogeneze. Fascinující jsou nejnovější nálezy, které svědčí pro možnost, že $\mathrm{IP}_{6}$ a vyšší fosforylované inositoly, které obsahují ve své molekule pyrofosfáty, se mohou podílet na fosforylaci proteinů (Saiardi et al., 2005). Dosud není s jistotou vyřešeno, zda a jak vzniká $\mathrm{IP}_{6} \mathrm{v}$ organismu živočichů de novo, avšak je zřejmé, že je prekurzorem pro difosfoinositolpentakisfosfát $\left(\mathrm{Ins}_{7}\right)$ a bis-difosfoinositoltetrakisfosfát (Ins $\left.\mathrm{P}_{8}\right)$, které se vyznačují vysokým obratem fosfátových skupin. Funkce vyšších inositolfosfátů $\mathrm{v}$ jemných regulačních fosforylacích různých proteinů by mohla vysvětlit rozmanité účinky $\mathrm{IP}_{6}$ pozorované na úrovni celého organismu.

\section{Kyselina fytová a buněčná signalizace}

Úloha inositol 1,4,5-trisfosfátu $\left(\mathrm{IP}_{3}\right)$ v buněčné signalizaci a $\mathrm{v}$ regulaci hladiny cytosolického vápníku se stala $\mathrm{v}$ posledních dvou dekádách všeobecně príijímanou a známou (Berridge, 2005). Poznání $\mathrm{IP}_{3}$ jako druhého posla poněkud zastínilo fakt, že prvním objeveným inositolfosfátem byla kyselina fytová. Rozvoj techniky HPLC, který umožnil studovat funkci $\mathrm{IP}_{3} \mathrm{v}$ mnoha buňkách a tkáních při rozmanitých biologických procesech, také odhalil vysoký obrat fosfátových skupin $\mathrm{IP}_{6}$ a jeho prítomnost ve tkáních živočichů. Úloha vyšších inositolfosfátů je v současné době intenzivně zkoumána, avšak stále není objasněná.

\section{Kyselina fytová a životní prostředí}

$\mathrm{V}$ místech s vysokou intenzitou živočišné výroby (chovy prasat a drůbeže) je $\mathrm{IP}_{6}$ hlavní př́ćcinou znečištění povrchových vod fosfáty. U zvířat s jednoduchým žaludkem není většina kyseliny fytové strávena, s výkaly odchází do kejdy a teprve tam podléhá mikrobiálnímu rozkladu za uvolnění fosfátů. Z toho důvodu se do krmiva prasat a drůbeže často prídává fytasa (Vohra, Satyanarayana, 2003). $\mathrm{IP}_{6}$ se využívá také jako součást kosmetických krémů, kde jsou zdůrazňovány její antioxidační a protizánětlivé účinky. Jako látka
E 391 je kyselina fytová součástí energetických nápojů, její používání však není našimi předpisy povoleno.

\section{ZÁVĚR}

Studium fosforylovaných inositolů jistě přinese mnohá překvapující zjištění, která nám vysvětlí fyziologický a biomedicínský význam tohoto nejrozšířenějšího inositolfosfátu ve světě. Již dnes však víme, že přiměřený přijem obilovin, ořechů a luštěnin je našemu zdraví prospěšný $\mathrm{v}$ každém věku. Lze předpokládat významnou úlohu kyseliny fytové v prevenci civilizačních onemocnění.

* Práce byla podporována grantem GAUK 13/2005.

\section{LITERATURA}

BERRIDGE, M. J.: Unlocking the secrets of cell signaling. Апnи Rev Physiol, 2005. Vol. 67, s.1-21.

GRAF, E., EATON, J. W.: Antioxidant functions of phytic acid. Free Radic. Biol. Med., 1990. Vol. 8, s. 61-69.

GRASES, F., SIMONET, B. M., VUCENIK, I. et al.: Effects of exogenous inositol hexakisphosphate (InsP (6)) on the levels of InsP (6) and of inositol trisphosphate (InsP (3)) in malignant cells, tissues and biological fluids. Life Sci., 2002. Vol. 71, s. $1535-1546$

HARLAND, B. F, MORRIS, E. R.: PHYTATE: a good or a bad food component? Nutr. Res., 1995. Vol. 15, s. 733-754.

IRVINE, R. F.: Inositide evolution - towards turtle domination? J. Physiol., 2005. Vol. 566, s. 295- 300.

OATWAY, L., VASANTHAN, T., HELM, J. H.: Phytic acid. Food Rev. Internat., 2001. Vol. 17, s. 419-431.

RABOY, V.: Myo-Inositol - 1,2,3,4,5,6 - hexakisphosphate. Phytochemistry, 2003, Vol. 64, s. 1033-1043.

SAIARDI, A., RESNICK, A. C., SNOWMAN, A. M. et al.: Inositol pyrophosphates regulate cell death and telomere length through phosphoinositide 3-kinase-related protein kinases. Proc. Natl. Acad. Sci. USA, 2005. Vol. 102, s. 1911 $-1914$

SANDBERG, A. - S., BRUNE, M., CARLSSON, N.-G. et al.: Inositol phosphates with different numbers of phosphate groups influence iron absorption in humans. Am. J. Clin. Nutr., 1999. Vol. 70, s. 240-246.

STRUNECKÁ, A.: Co víme a nevíme o kyselině fytové nejrozšířeněǰším inositolfosfátu na Zemi. Čs. fyziol., 2006. Vol. 55, s. 45-46.

VOHRA, A., SATYANARAYANA, T.: Phytases: microbial sources, production, purification, and potential biotechnological applications. Crit. Rev, Biotechnol., 2003. Vol. 23, s. 29-60.

YANG, S. N., YU J., MAYR, G. W. et al.: Inositol hexakisphosphate increases L-type $\mathrm{Ca} 2+$ channel activity by stimulation of adenylyl cyclase. Faseb. J., 2001. Vol. 15, s. $1753-1763$.

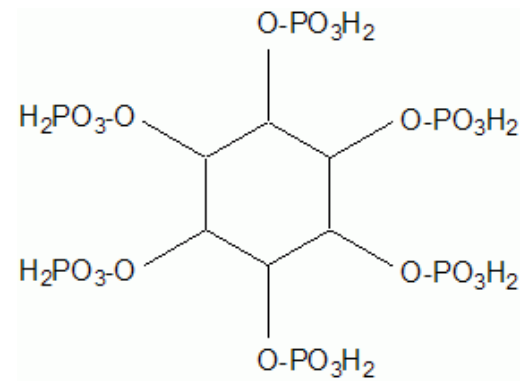

$\hookleftarrow$ Obr 1: Chemická struktura $\mathrm{IP}_{6}$
Anna Strunecká a Jiří Patočka strun@natur.cuni.cz 